\title{
Solitary fibrous tumor involving urinary bladder: a case report and literature review
}

\author{
Shengjie Sun", Min Tang", Huiyu Dong", Chao Liang, Tao Yan, Junchen Li, Bianjiang Liu, Jie Li \\ State Key Laboratory of Reproductive Medicine and Department of Urology, The First Affiliated Hospital of Nanjing Medical University, Nanjing \\ 210000, China \\ "These authors contributed equally to this work. \\ Correspondence to: Jie Li; Bianjiang Liu. State Key Laboratory of Reproductive Medicine and Department of Urology, The First Affiliated Hospital of \\ Nanjing Medical University, Nanjing 210000, China. Email: drc_lijie@126.com; bjliu@njmu.edu.cn.
}

\begin{abstract}
Solitary fibrous tumor (SFT) is a rare fibroblast stroma tumor involving the mediastinum and pleura. We herein describe an SFT of bladder which is extremely rare and review 29 similar cases in the last decades. We present a case of a 52-year-old male patient who suffered from urinary urgency and frequency for 12 months. Non-contrast computed tomography (CT) showed a slightly high density calcified mass with $70 \mathrm{~mm} \times 61 \mathrm{~mm}$ in diameter. Contrast-enhanced CT demonstrated the mass was slightly enhanced. Cystoscopy revealed a huge mass with flat surface. Histopathological review of the biopsy specimens could not confirm the diagnosis. Partial cystectomy was then performed and the diagnosis of SFT was confirmed by immunohistochemistry. The patient is doing well at 12 months followup without recurrence and metastasis. In conclusion, the diagnosis of SFT involving bladder should combine clinical presentation and imaging features. Complete surgical resection is the primary method and long-term follow-up is necessary.
\end{abstract}

Keywords: Case report; review; solitary fibrous tumor (SFT); urinary bladder.

Submitted Dec 10, 2019. Accepted for publication Jan 06, 2020.

doi: $10.21037 /$ tau.2020.01.09

View this article at: http://dx.doi.org/10.21037/tau.2020.01.09

\section{Introduction}

Solitary fibrous tumor (SFT) is a rare fibroblast stroma tumor involving the mediastinum and pleura (1). The tumor is the most common diagnosed between 40 to 70 years old and the incidence rate is the same in males and females. SFT most commonly occur in the pleura and abdomen, only few cases of SFTs of bladder have been reported in the literature. The aim of this article is to present this rare case and review 29 similar cases reported in the literature in the last decade. We present the following case in accordance with the CARE Guideline (2).

\section{Case presentation}

A 52-year-old male Asian patient had suffered from urinary urgency and frequency since August 2017. Therefore, he visited the local hospital and received simple urine analysis, which showed lower urinary tract infection. Then he was recommended to take levofloxacin to control the infection. The symptoms were partially relieved, but persisted and went worse in a year. He then accepted abdomen non-contrast CT, which revealed a slightly highdensity calcified mass with $70 \mathrm{~mm} \times 61 \mathrm{~mm}$ in diameter suspected as bladder cancer, locating on the right wall of bladder. He was transferred to our department. After admission, further contrast-enhanced CT was done and it demonstrated the mass was slightly enhanced and invading the bladder wall (Figure 1). Next, the patient underwent cystoscopy and it revealed a huge mass with flat surface, but the panorama could not be accurately manifested due to serious intravesical bleeding and the small bladder capacity 

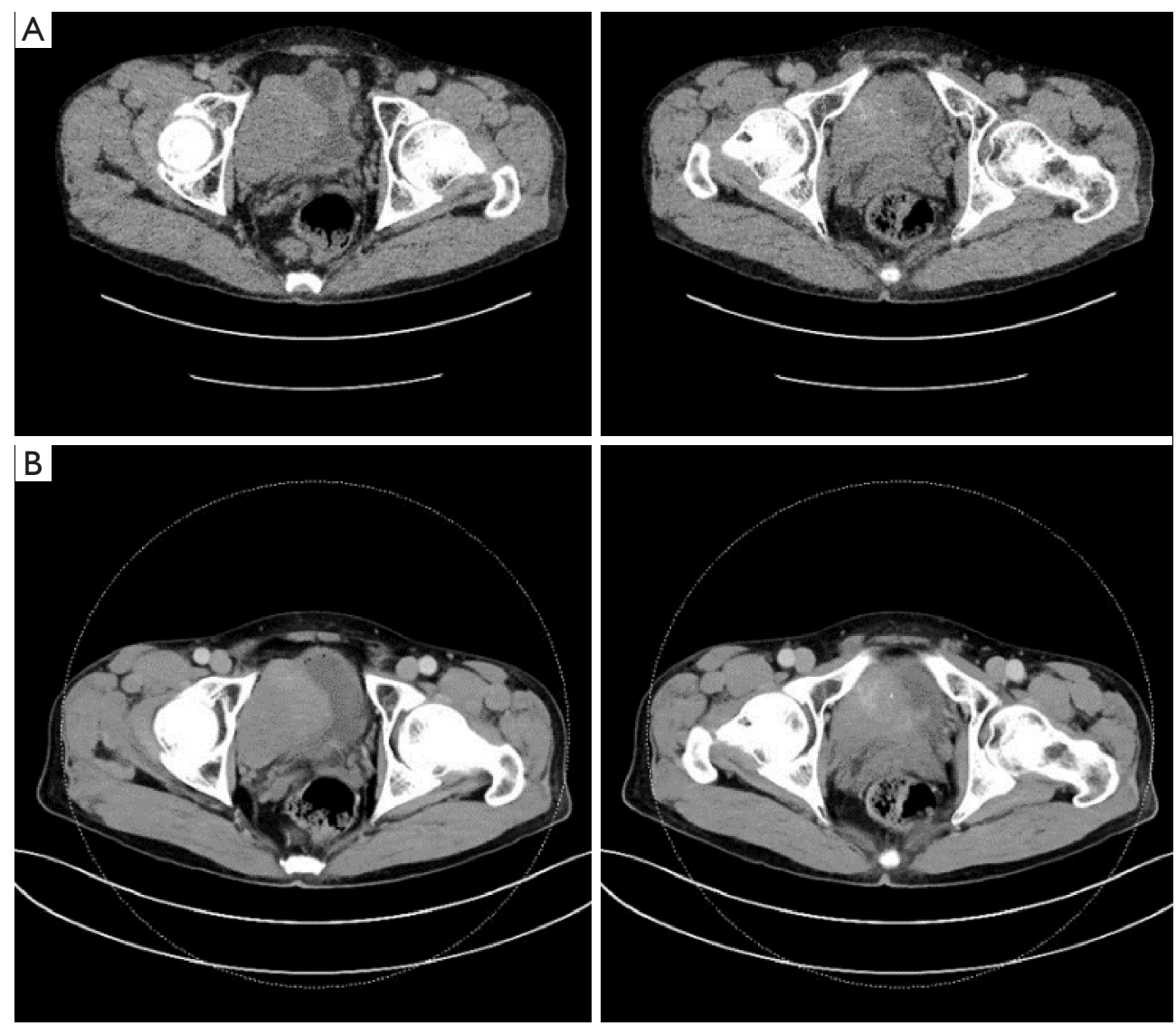

Figure 1 Preoperative CT. (A) Non-contrast CT showed a slightly high-density mass, calcification inside. (B) Enhanced CT demonstrated the mass was slightly enhanced.

that patient was hard to bear during the examination. Histopathological review of the biopsy specimens could not confirm the diagnosis. Finally, partial cystectomy was recommended. he had an unremarkable medical, surgical, and family history. On admission, his physical examination and laboratory data were also unremarkable. Preoperative CT evaluation did not find evidence of metastasis in both lungs and abdominal organs.

In the surgery, we chose a lower abdominal median incision to expose the bladder step by step. With a longitudinal incision of the bladder, we could see the bulge of the bladder mucosa on the right which is about $5 \mathrm{~cm}$ in diameter. Then we removed the tumor completely including $1 \mathrm{~cm}$ of normal bladder tissue around, during which the bilateral ureteral orifices were recognized and protected by the ureteral catheters. We finally closed the bladder retaining bladder stoma, pelvic drainage tube and urethral catheter which were removed 5, 6 and 7 days separately after the surgery. The patient tolerated the procedure well and there were no adverse events. The IHC (immunohistochemistry) showed expression of CD34, Bcl-2, PR, Ki67 (+2\%), and negative for CK-pan, SMA, Desmin, DOG-1, ALK p80, S-100, thus the tumor was diagnostic as SFT (Figure 2). After 12 months of follow-up, the symptoms of the patient were significantly relieved. The abdominal CT (Figure 3) confirmed no signs of recurrence and distant metastasis (Figure 4).

\section{Discussion and review of the literature}

\section{Epidemiology and origin}

SFT was first described in 1931 by Klemperer (3). Originally, SFT was described as the tumor involving the mediastinum and pleura. However, with the increasing 


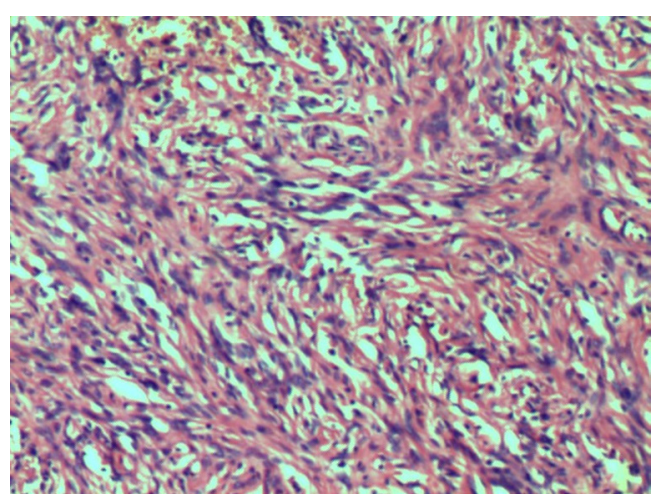

Figure 2 The tumor was mainly composed of spindle cell. Based on hematoxylin and eosin staining. Magnification: $\times 20$. reports in recent years, it has been established that SFT can occur widely in many organs including peritoneum, retroperitoneal, pericardium, gastrointestinal tract, kidney, adrenal gland, paranasal sinuses, orbit and so on. SFT arises from dendritic interstitial cells with positivity for CD34. It is a kind of non-directed differentiated stromal tumor, which can differentiate into fibroblasts, myofibroblasts, vascular cortical cells and vascular endothelial cells (4). According to the literature reports of 160 patients with SFT in the abdomen, until 2010, 28 were found in the liver, 25 in the prostate, 20 in the kidney, 12 in the retroperitoneal, and only 10 in the bladder (5). In view of its rarity, we are reporting this case to date and review of 29 cases of SFT

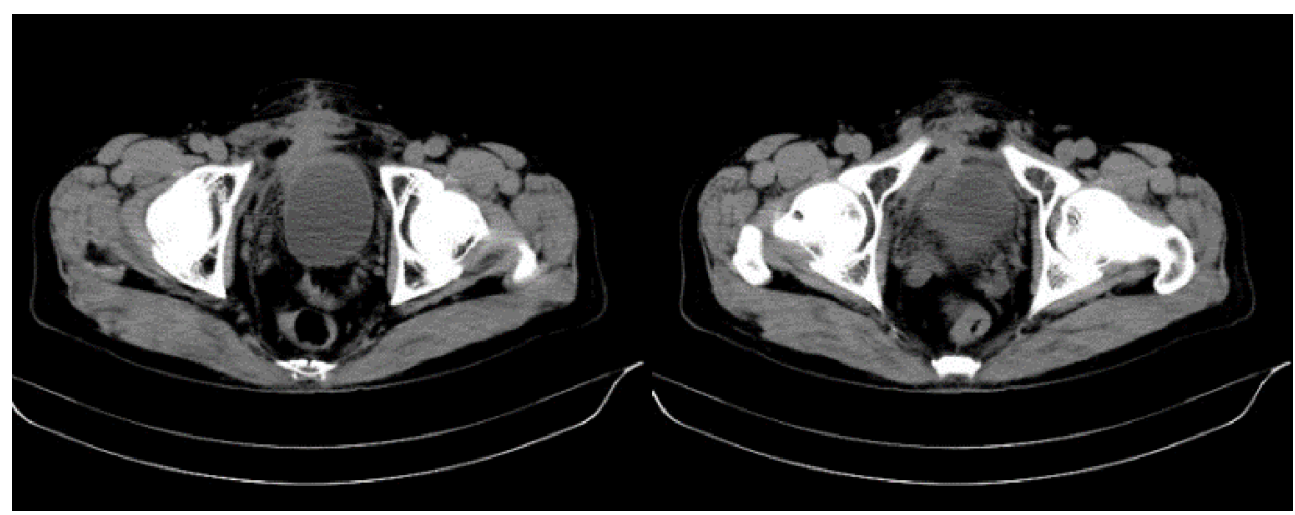

Figure 3 Abdomen non-contrast CT showed that the bladder capacity had partially recovered 12 months after operation.

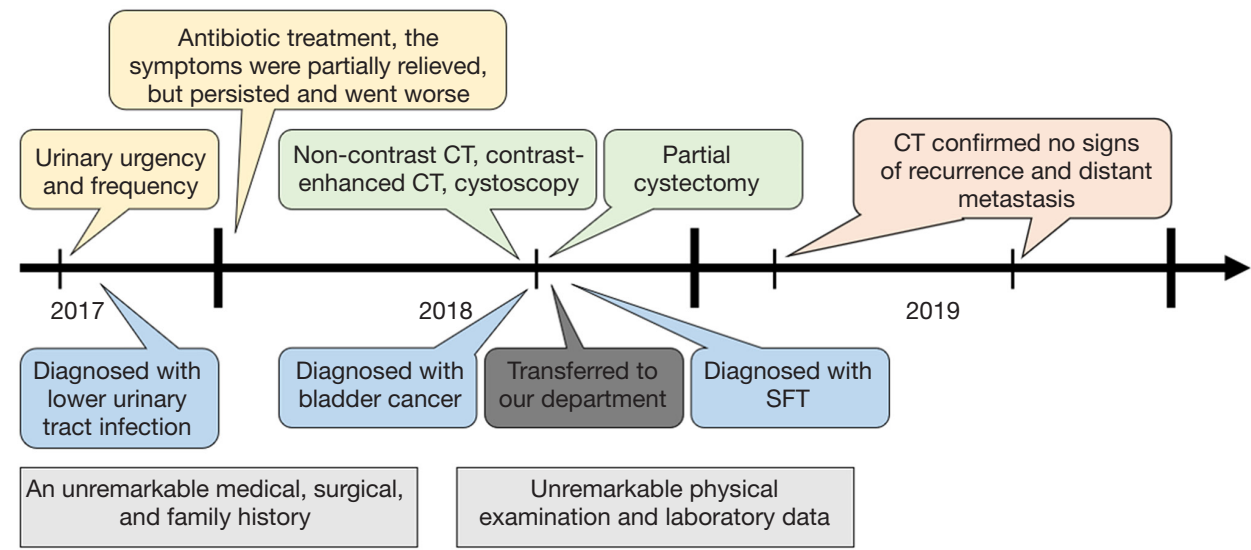

Figure 4 The timeline of the disease course. 
involving bladder (Tables 1,2).

In our review, the age of onset of SFT patients was 11 to 85 years, while the mean age was 56.8 years and the median age was 60 years. The sex ratio with the patients is 7 females to 23 males, revealing a male predilection.

\section{Diagnosis}

Clinical feature was mostly related to tumor volume. Symptoms may occur when tumor volume is large and compresses surrounding tissues or organs. The most common symptoms were abdominal pain $(9 / 28,32.1 \%)$ and dysuria even urine retention $(9 / 28,32.1 \%)$, followed by hematuria $(7 / 28,25 \%)$, urinary urgency $(6 / 28,21.4 \%)$, urination pain $(5 / 28,17.9 \%)$, abdominal swelling or palpable mass $(5 / 28,17.9 \%)$, gastrointestinal symptoms $(3 / 28,10.7 \%)$, hypoglycemia $(3 / 28,10.7 \%)$, weight loss $(2 / 28,7.1 \%)$ and 5 patients $(5 / 28,17.9 \%)$ were incidental finding. Tumor sizes have ranged from 0.85 to $28 \mathrm{~cm}$, while the mean sizes were $10 \mathrm{~cm}$.

On imaging, ultrasonic diagnostics generally presents as hypoechoic mass, clear boundary and uneven internal echoes, which is non-specific. Color Doppler showed blood flow signals in some cases. It is worth mentioning that the SFT favors malignancy, if hemodynamics shows low resistant index (RI) (31). CT or magnetic resonance imaging (MRI) helps to identify SFT and decide operation method. Yet, the features of CT or MRI are non-specific. Larger SFT was isodense with some hypodense areas caused by necrotic, myxoid or cystic changes on unenhanced CT while small SFT was isointense in both on CT and MRI (32). Some studies consider that rich blood vessels are reliable signs of SFT (33).

Due to the absence of specific clinical manifestations special characters in iconography and exclusive tumor markers, this disease is neglected frequently in the early stage. Currently, histopathology and immunohistochemistry are the main evidence for the diagnosis of SFT. With the

Table 1 Case reports of literature review (patient information)

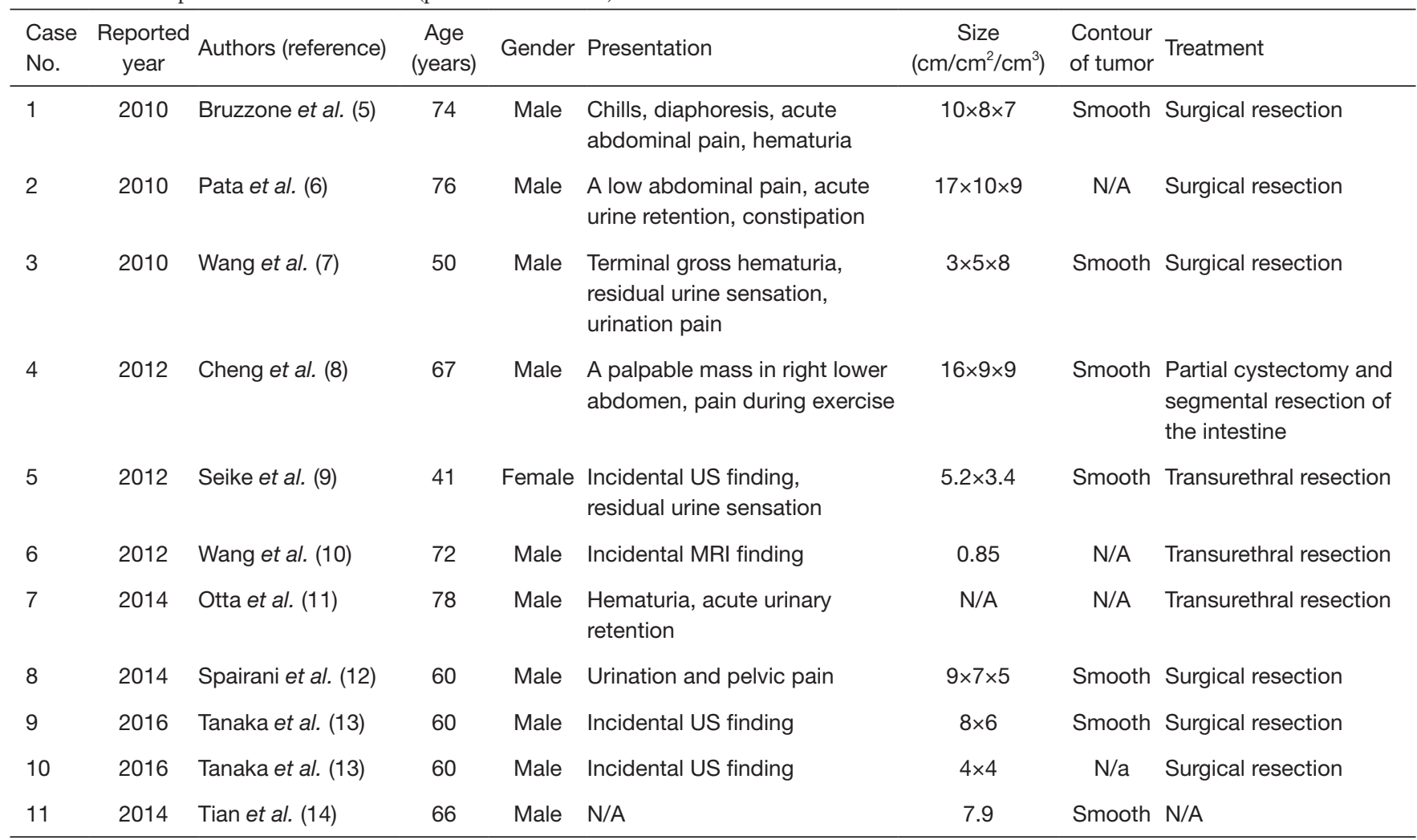

Table 1 (Continued) 
Table 1 (Continued)

\begin{tabular}{|c|c|c|c|c|c|c|c|c|}
\hline $\begin{array}{l}\text { Case } \\
\text { No. }\end{array}$ & $\begin{array}{l}\text { Reported } \\
\text { year }\end{array}$ & Authors (reference) & $\begin{array}{c}\text { Age } \\
\text { (years) }\end{array}$ & Gender & Presentation & $\begin{array}{c}\text { Size } \\
\left(\mathrm{cm} / \mathrm{cm}^{2} / \mathrm{cm}^{3}\right)\end{array}$ & $\begin{array}{l}\text { Contour } \\
\text { of tumor }\end{array}$ & Treatment \\
\hline 12 & 2014 & Chen et al. (15) & 40 & Female & $\begin{array}{l}\text { Incidental physical examination } \\
\text { finding }\end{array}$ & $5 \times 5$ & Smooth & $\begin{array}{l}\text { Laparoscopic partial } \\
\text { resection of bladder } \\
\text { tumor }\end{array}$ \\
\hline 13 & 2015 & Aji et al. (16) & 60 & Female & $\begin{array}{l}\text { Progressive worsening } \\
\text { of the flow of urine }\end{array}$ & $1.2 \times 0.9$ & $\mathrm{~N} / \mathrm{A}$ & Transurethral resection \\
\hline 15 & 2015 & Gao et al. (18) & 52 & Male & $\begin{array}{l}\text { A mass in the right lower } \\
\text { quadrant }\end{array}$ & $9.3 \times 6.5$ & $\begin{array}{l}\text { Not } \\
\text { smooth }\end{array}$ & $\begin{array}{l}\text { Pelvic tumor resection; } \\
\text { postoperative } \\
\text { radiation therapy and } \\
\text { chemotherapy }\end{array}$ \\
\hline 17 & 2016 & Mustafa et al. (20) & 36 & Female & $\begin{array}{l}\text { Symptomatic anemia, } \\
\text { urinary frequency, } \\
\text { increased abdominal girth }\end{array}$ & $6.7 \times 7.5 \times 7.2$ & Smooth & Surgical resection \\
\hline 18 & 2016 & Ruan et al. (21) & 65 & Male & Hematuria, urination pain & $5.6 \times 4.6 \times 4.0$ & $\mathrm{~N} / \mathrm{A}$ & Surgical resection \\
\hline 19 & 2016 & Tong et al. (22) & 85 & Female & $\begin{array}{l}\text { Dysuria, urination pain, left } \\
\text { abdominal pain }\end{array}$ & $12.3 \times 10.5$ & Smooth & Surgical resection \\
\hline 20 & 2017 & Kouba et al. (23) & 33 & Female & Hypoglycemia & 3.5 & $\mathrm{~N} / \mathrm{A}$ & Transurethral resection \\
\hline 21 & 2017 & Kouba et al. (23) & 41 & Male & Urinary obstruction & 5.7 & $\mathrm{~N} / \mathrm{A}$ & Surgical resection \\
\hline 26 & 2019 & Rovegno et al. (27) & 69 & Male & $\begin{array}{l}\text { Abdominal pain, hematuria, } \\
\text { low urinary tract symptoms }\end{array}$ & $10 \times 8$ & $\begin{array}{l}\text { Not } \\
\text { smooth }\end{array}$ & $\begin{array}{l}\text { Radical } \\
\text { cystoprostatectomy }\end{array}$ \\
\hline 27 & 2019 & Cheng et al. (28) & 43 & Male & Hematuria & $8 \times 4.5 \times 3.5$ & Smooth & $\begin{array}{l}\text { Robotic laparoscopic } \\
\text { resection of pelvic tumor } \\
\text { through bladder }\end{array}$ \\
\hline 28 & 2019 & Kratiras et al. (29) & 31 & Male & $\begin{array}{l}\text { Frank hematuria, dysuria, dull } \\
\text { abdominal pain }\end{array}$ & $4.2 \times 5.3$ & $\mathrm{~N} / \mathrm{A}$ & Transurethral resection \\
\hline 29 & 2019 & $\begin{array}{l}\text { Urbina-Lima et al. } \\
\text { (30) }\end{array}$ & 61 & Male & $\begin{array}{l}\text { Hypoglycemia, generalized } \\
\text { asthenia, weight loss }\end{array}$ & $15 \times 23 \times 22$ & Smooth & Surgical resection \\
\hline 30 & 2019 & Our case & 52 & Male & Urinary urgency and frequency & $7 \times 6.1$ & Smooth & Partial cystectomy \\
\hline
\end{tabular}

N/A, not available. 
naked eye, tumors showed soft tissue density, clear boundaries and may have cystic areas, calcification, mucoid degeneration or hemorrhage, etc. (34). While in histology, the tumor cells are fusiform and alternately distributed between the dense region (less collagen) and the loose region (abundant collagen) (35). CD34, vimentin, beta-catenin, CD99 and Bcl-2 showed positivity, while CK, EMA, CK-pan, SMA, Calretinin, Desmin, CD56, CD117 or S-100 were lost (26). The CD34 positive expression rate is closely related to the degree of differentiation of tumor cells, it is higher in benign tumors while it decreases in malignant tumors, and is considered to be a specific and essential indicator for the diagnosis of SFT (36). In recent years, some studies have shown that STAT6 can be used as a specific marker of SFT. In this review, all patients could obtain immunohistochemical results showed CD34 positive and 5 of the 7 patients showed STAT6 positive. Malignant SFTs have large tumor size with necrosis and hemorrhage, infiltrative borders, high mitotic count, increased cellularity and cellular pleomorphism $(1,26)$.

\section{Treatment and management}

Complete surgical resection is the primary method for the treatment of all SFT. For the patients undergoing surgery, surgical excision with negative margins is the most important factor affecting its prognosis. Chemotherapy can be used for SFT that has been metastasizing or unresectable, but there is currently no clear indication of chemotherapy. The most effective drugs are anthracyclines antibiotic and ifosfamide, supplemented by 2,2-difluorocytosine deoxynucleoside and dacarbazine (37). All the patients in this review underwent surgical resection, and one patient with recurrence underwent postoperative radiation therapy and chemotherapy. There are only minor complications associated with treatment which is not specific.

The invasiveness and prognosis of SFT are difficult to confirm. Lots of cases in the literature show that the vast majority of SFT manifested as benign, and no recurrence was found after long-term follow-up, still there was potential for metastasis or recurrence (38). In Table 2, $1(1 / 27,3.7 \%)$ of the 27 patients developed distant metastasis and $5(5 / 27,18.5 \%)$ presented local recurrence. Unfortunately, due to the lack of data, we are unable to judge the accuracy of risk stratification model for SFT, published by Demicco et al. recently, based on the data collected. In the analysis of SFT patients published to date, there was no metastasis in the low-risk group, $7 \%$ of the 10 -year metastasis risk in the moderate-risk group, and 49\% 5-year metastasis risk in the high-risk group (39). Therefore, long-term follow-up is necessary for SFT such as examining abdomen CT every 6 month.

\section{Conclusions}

In this paper, we described a rare case of SFT involving bladder and review 29 similar cases in the last decades. The diagnosis of SFT involving bladder should combine clinical presentation and imaging features. Furthermore, cystoscopy and tissue biopsy can assist at times. However, immunohistochemistry is the main proof for the diagnosis of SFT. Complete surgical resection is the primary method, while the method of operation can be open, laparoscopic or robot-assisted. Because of the potential for metastasis or recurrence, long-term follow-up is necessary.

Table 2 Case reports of literature review (postoperative situation)

\begin{tabular}{|c|c|c|c|c|c|c|c|c|}
\hline $\begin{array}{l}\text { Case } \\
\text { No. }\end{array}$ & $\begin{array}{l}\text { Mitotic count } \\
\text { (density-power } \\
\text { fields) }\end{array}$ & $\begin{array}{c}\text { Tumor } \\
\text { necrosis }\end{array}$ & Immunohistochemical & $\begin{array}{l}\text { Follow-up } \\
\text { (months) }\end{array}$ & $\begin{array}{l}\text { Recurrence/ } \\
\text { metastasis } \\
\text { (months) }\end{array}$ & Complications & $\begin{array}{l}\text { Risk stratification } \\
\text { model score }\end{array}$ & $\begin{array}{l}\text { Risk } \\
\text { class }\end{array}$ \\
\hline 2 & $\mathrm{~N} / \mathrm{A}$ & $\mathrm{N} / \mathrm{A}$ & CD34+, Bcl-2+, CD99+ & 5 & None/none & None & $\mathrm{N} / \mathrm{A}$ & $\mathrm{N} / \mathrm{A}$ \\
\hline 3 & $\mathrm{~N} / \mathrm{A}$ & $\mathrm{N} / \mathrm{A}$ & $\begin{array}{l}\text { Vimentin+, CD34+/calponin-, } \\
\text { S-100-, ALK-, CD117-, } \\
\text { CK19-, SMA- }\end{array}$ & 9 & None/none & None & $\mathrm{N} / \mathrm{A}$ & $\mathrm{N} / \mathrm{A}$ \\
\hline 4 & $>4 / 10$ & Present & $\begin{array}{l}\text { CD34+, CD99+/CD117-, } \\
\text { SMA-, CKAE1- }\end{array}$ & 18 & None/none & None & 7 & High \\
\hline
\end{tabular}

Table 2 (Continued) 
Table 2 (Continued)

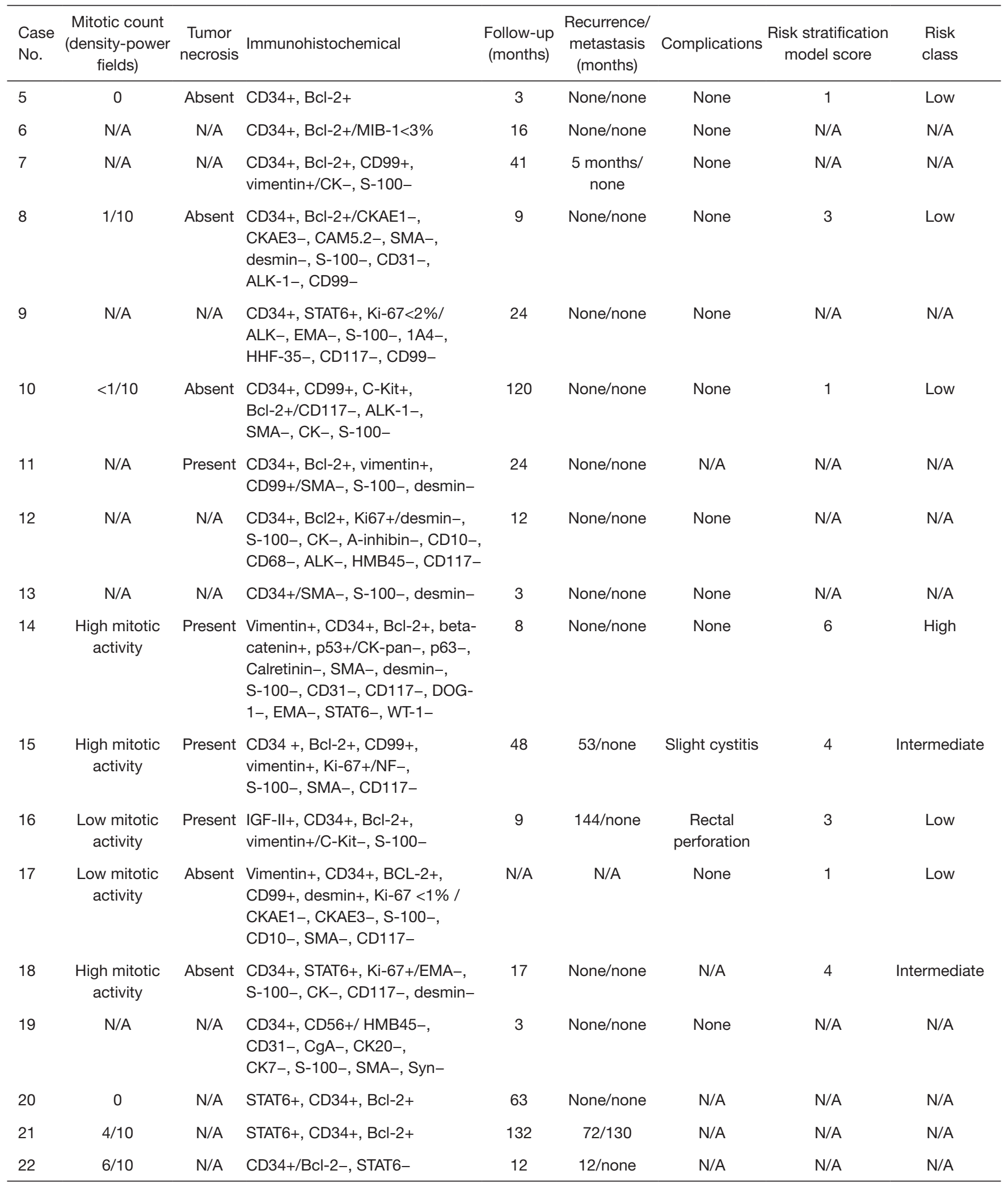

Table 2 (Continued) 
Table 2 (Continued)

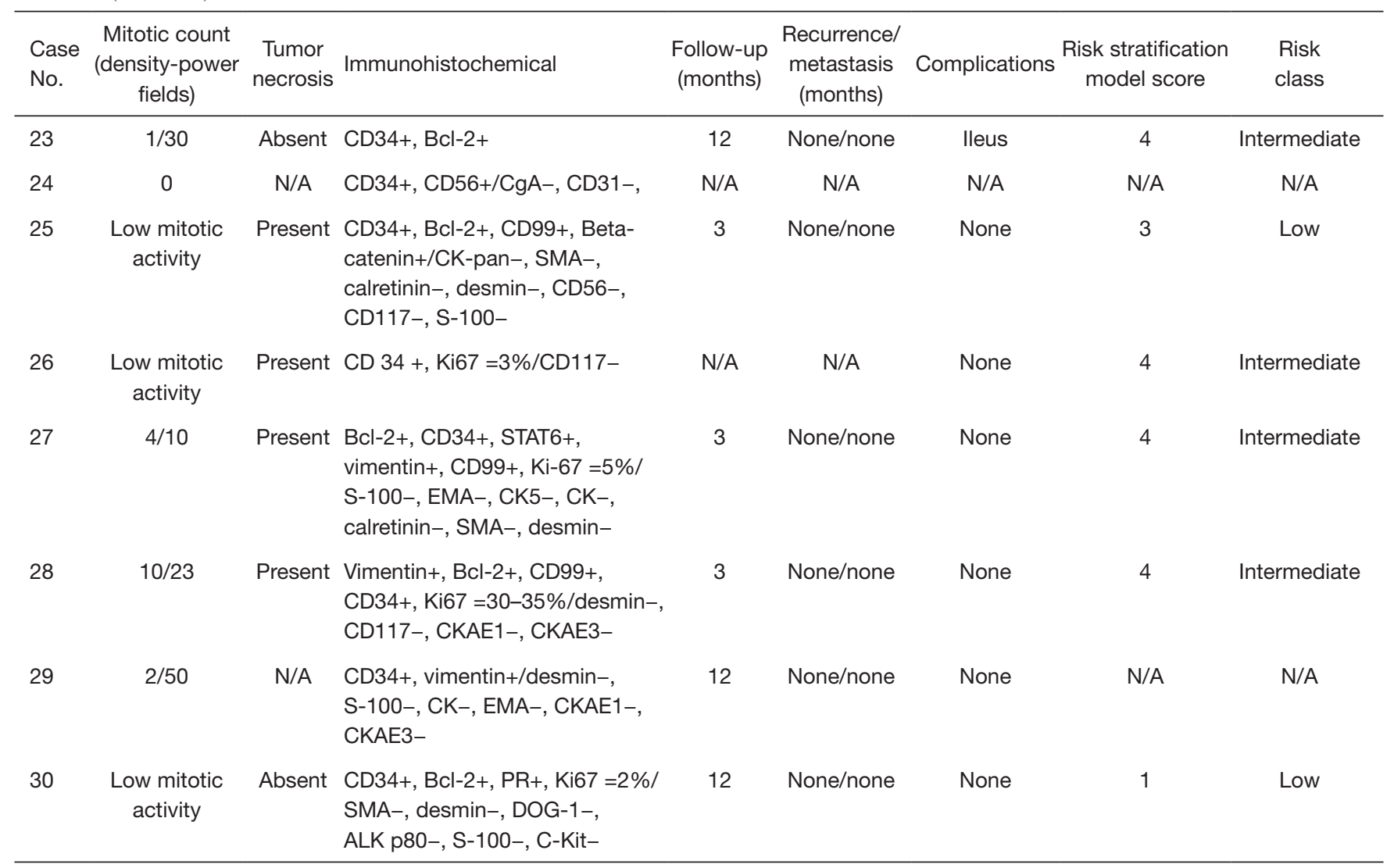

CD34, cluster of differentiation 34; Bcl-2, B-cell lymphoma-2; CD99, cluster of differentiation 99; ALK, anaplastic lymphoma kinase; CD117, cluster of differentiation 117; CK19, cytokeratin 19; SMA, smooth muscle actin; CKAE1/CKAE3, cytokeratin AE 1/cytokeratin AE 3; MIB-1, molecular immunology Borstel number 1; CD31, cluster of differentiation 31; STAT6, activator of transcription 6; Ki-67, Ki67 protein; EMA, epithelial membrane antigen; CD10, cluster of differentiation 10; CD68, cluster of differentiation 68; HMB45, melanoma marker antibody; CK-pan, pan-cytokeratin; WT-1, Wilms tumor 1 protein; IGF-II, insulin-like growth factor II; CgA, chromogranin A; Syn, synaptophysin; CD20, cluster of differentiation 20; CD7, cluster of differentiation 7.

\section{Acknowledgments}

Funding: This work was supported by the National Natural Science Foundation of China (grant No. 81600514 and 81672532), the grant from Six Talent Peak Project of High-level Talents in Jiangsu Province (WSW-017), 333 High-level Talents Training Project in Jiangsu Province, Professional from Six-Pronged Top-Talent Program (LGY2018053), Qing Lan Project of Jiangsu University (JX2161015100), The Fifth Batch of Outstanding Young and Middle-aged Teachers' Support Program of Nanjing Medical University, A Project Funded by the Priority Academic Program Development of Jiangsu Higher Education Institutions (JX10231802), Jiangsu Natural Science Foundation (No. BK20191077), and Postgraduate
Research \& Practice Innovation Program of Jiangsu Province (KYCX18_1488).

\section{Footnote}

Conflicts of Interest: All authors have completed the ICMJE uniform disclosure form (available at http://dx.doi. org/10.21037/tau.2020.01.09). The authors have no conflicts of interest to declare.

Ethical Statement: The authors are accountable for all aspects of the work in ensuring that questions related to the accuracy or integrity of any part of the work are appropriately investigated and resolved. Written informed consent was obtained from the patient for 
publication of this manuscript and any accompanying images.

Open Access Statement: This is an Open Access article distributed in accordance with the Creative Commons Attribution-NonCommercial-NoDerivs 4.0 International License (CC BY-NC-ND 4.0), which permits the noncommercial replication and distribution of the article with the strict proviso that no changes or edits are made and the original work is properly cited (including links to both the formal publication through the relevant DOI and the license). See: https://creativecommons.org/licenses/by-ncnd/4.0/.

\section{References}

1. Fletcher CDM. WHO classification of tumors of soft tissue and bone. IARC Press; 2013.

2. Riley DS, Barber MS, Kienle GS, et al. CARE guidelines for case reports: explanation and elaboration document. J Clin Epidemiol 2017;89:218-35.

3. Cerda NM, Lopez GC, Gil BR, et al. Solitary fibrous tumor of the orbit: morphological, cytogenetic and molecular features. Neuropathology 2006;26:557-63.

4. Poyraz A, Kilic D, Hatipoglu A, et al. Pedunculated solitary fibrous tumours arising from the pleura. Monaldi Arch Chest Dis 2006;65:165-8.

5. Bruzzone A, Varaldo M, Ferrarazzo C, et al. Solitary fibrous tumor. Rare Tumors 2010;2:e64.

6. Pata F, Orsini V, Lucisano AM, et al. Solitary fibrous tumor of the pelvis: an uncommon soft-tissue tumor. A case report. Ann Ital Chir 2010;81:457-60.

7. Wang T, Chen R, Qiao J, et al. Solitary fibrous tumor in bladder: a case report. J Huazhong Univ Sci Technolog Med Sci 2010;30:412-4.

8. Cheng SH, Wang SS, Lee CH, et al. Malignant solitary fibrous tumor of the urinary bladder. J Chin Med Assoc 2012;75:479-82.

9. Seike K, Kameyama K, Kato T, et al. Solitary fibrous tumor of the urinary bladder: a case report. Hinyokika Kiyo 2012;58:105-8.

10. Wang C, Miyago N, Harada Y, et al. Solitary fibrous tumor of the urinary bladder: a case report. Nihon Hinyokika Gakkai Zasshi 2012;103:640-3.

11. Otta RJ, Acosta MA, Gordillo C. A rare case of solitary fibrous tumour of the bladder. Can Urol Assoc J 2014;8:E552-3.

12. Spairani C, Squillaci S, Pitino A, et al. A case of concomitant occurrence of solitary fibrous tumor and urothelial high-grade invasive carcinoma of the urinary bladder. Int J Surg Pathol 2014;22:252-9.

13. Tanaka EY, Buonfiglio VB, Manzano JP, et al. Two Cases of Solitary Fibrous Tumor Involving Urinary Bladder and a Review of the Literature. Case Rep Urol 2016;2016:5145789.

14. Tian TT, $\mathrm{Wu} \mathrm{JT}, \mathrm{Hu} \mathrm{XH}$, et al. Imaging findings of solitary fibrous tumor in the abdomen and pelvis. Abdom Imaging 2014;39:1323-9.

15. Chen Y, Zhu S, Liu G, et al. One case report of solitary fibrous tumor and literature review. J Clin Urology (China) 2014;29:405-7.

16. Aji SA, Gupta NP. Solitary fibrous tumor mimicking prolapsed ureteral polyp. Indian J Urol 2015;31:358-9.

17. Dozier J, Jameel Z, McCain DA, et al. Massive malignant solitary fibrous tumor arising from the bladder serosa: a case report. J Med Case Rep 2015;9:46.

18. Gao C, Zhang Y, Li YY, et al. Postoperative recurrence solitary fibrous tumor of the pelvic with malignant transformation. Int J Clin Exp Med 2015;8:16827-33.

19. Ishihara $\mathrm{H}$, Omae $\mathrm{K}$, Iizuka J, et al. Late recurrence of a malignant hypoglycemia-inducing pelvic solitary fibrous tumor secreting high-molecular-weight insulin-like growth factor-II: A case report with protein analysis. Oncol Lett 2016;12:479-84.

20. Mustafa HJ, Menon S. Solitary Fibrous Tumor in a Female Urinary Bladder. Urol Case Rep 2016;7:1-2.

21. Ruan HJ, Huang AH, Cheng S, et al. Clinicopathologic features of solitary fibrous tumor in urogenital system. Zhonghua Bing Li Xue Za Zhi 2016;45:248-51.

22. Tong XN, Cheng T, Zhang M, et al. A Case of Huge Solitary Fibrous Tumor in Bladder. Clin Genitourin Cancer 2016;15:e105-10.

23. Kouba E, Simper NB, Chen S, et al. Solitary fibrous tumour of the genitourinary tract: a clinicopathological study of 11 cases and their association with the NAB2STAT6 fusion gene. J Clin Pathol 2017;70:508-14.

24. Tan GHC, Ng D, Hennedige T, et al. A solitary fibrous tumour mimicking an aggressive angiomyxoma/ liposarcoma. BMJ Case Rep 2017;2017:1-4.

25. Wu RJ, Zhang H, Wang XC, et al. Solitary fibrous tumor of bladder: a report of one case: imaging and patholog. Chin J Magn Reson Imaging 2017;8:140-2.

26. Prunty MC, Gaballah A, Ellis L, et al. Solitary Fibrous Tumor of the Pelvis Involving the Urinary Bladder. Urology 2018;117:27-30.

27. Rovegno FA, Hernandez CY, Gradin S, et al. Solitary 
Fibrous Tumor of the pelvis involving the bladder. Case report and literature review. Urol Case Rep 2019;24:100864.

28. Cheng Q, Chang X, Chen W, et al. A rare case of solitary fibrous tumor arising from prostate located inside of bladder. Urol Case Rep 2019;24:100880.

29. Kratiras Z, Spapis V, Koniaris E, et al. Malignant solitary fibrous tumor of urinary bladder: A rare clinical entity. Arch Ital Urol Androl 2019. doi: 10.4081/aiua.2019.2.135.

30. Urbina-Lima AD, Roman-Martin AA, Crespo-Santos A, et al. Solitary Fibrous Tumor of the Urinary Bladder Associated with Hypoglycemia: An Unusual Case of Doege-Potter Syndrome. Urol Int 2019;103:120-4.

31. Xiao X, Housheng X, Jie Y. The ultrasound diagnosis and pathologic analysis of solitary fibrous tumors in 6 cases. $\mathrm{J}$ Bengbu Med Coll 2013;38:1334-7.

32. Zhanlong M, Haibin S, Xiangshan F, et al. Variable Solitary Fibrous Tumor Locations: CT and MR Imaging Features. Medicine (Baltimore) 2016;95:e3031.

33. Shin SS, Jeong YY, Kang HK. Myxoid solitary fibrous tumor of the retroperitoneum: MRI findings with the pathologic correlation. Korean J Radiol 2008;9:279-82.

Cite this article as: Sun S, Tang M, Dong H, Liang C, Yan T, Li J, Liu B, Li J. Solitary fibrous tumor involving urinary bladder: a case report and literature review. Transl Androl Urol 2020;9(2):766-775. doi: 10.21037/tau.2020.01.09
34. Zhang GJ, Li RT, Zhou Y, et al. Solitary fibrous tumor of small bowel mesentery with postoperative bowel obstruction: a case report and review of literature. Int J Clin Exp Pathol 2015;8:11691-7.

35. Hui M, Xu Y, Zhang N, et al. Clinical characteristics of abdominal solitary fibrous tumor: an analysis of 18 cases. Zhonghua Yi Xue Za Zhi 2018;98:1439-42.

36. Mosquera JM, Fletcher CD. Expanding the spectrum of malignant progression in solitary fibrous tumors: a study of 8 cases with a discrete anaplastic component--is this dedifferentiated SFT? Am J Surg Pathol 2009;33:1314-21.

37. Grobmyer SR, Maki RG, Demetri GD, et al. Neoadjuvant chemotherapy for primary high-grade extremity soft tissue sarcoma. Ann Oncol 2004;15:1667-72.

38. Magro G, Emmanuele C, Lopes M, et al. Solitary fibrous tumour of the kidney with sarcomatous overgrowth. Case report and review of the literature. Apmis 2008;116:1020-5.

39. Demicco EG, Wagner MJ, Maki RG, et al. Risk assessment in solitary fibrous tumors: validation and refinement of a risk stratification model. Mod Pathol 2017;30:1433-42. 